Gut, 1969, 10, 723-729

\title{
Gastrointestinal motility and gastric secretion during intravenous infusions of gastrin II
}

\author{
J. J. MISIEWICZ, SHEILA L. WALlER, AND \\ D. J. HOLDSTOCK \\ From the Medical Research Council Gastroenterology Unit, \\ Central Middlesex Hospital, London
}

SUMMARY The effect of intravenous infusion of gastrin II on gastric and colonic motor activity was studied in 12 patients; gastric acid output was also measured. Administration of gastrin at nearmaximal dose levels stimulates the motor activity of the antrum but has no measurable effect on the activity of the proximal colon, sigmoid, or rectum. The results suggest that gastrin plays a part in the regulation of gastric motility but that it is not a mediator of the gastro-colic reflex.

In this paper we report the effects of gastrin II infused intravenously, in doses that produce submaximal stimulation of gastric acid secretion, on gastric and colonic motility. The aim was to simulate with exogenous gastrin such physiological responses to food as may occur in man (Rune, 1966) in response to endogenous gastrin. The present results are compared with earlier studies, in which similar observations were made during the intravenous infusion of pentagastrin (Misiewicz, Holdstock, and Waller, 1967).

\section{PATIENTS AND METHODS}

Simultaneous measurements of gastric acid output and of intraluminal pressures in the stomach and the proximal and distal colon were made in 12 patients, who were referred either for gastric secretory studies or for tests of colonic motility. The additional procedures involved were carefully explained and the patients were free to decline them if they so wished; in the event they all agreed to the test. Six of the patients had duodenal ulcers, one had a gastric ulcer, and the remaining five suffered from functional disorders of the bowel.

DOSE OF GASTRIN AND DESIGN OF STUDY Pure porcine gastrin II was used throughout. The dosage was based on the data of Makhlouf, McManus, and Card (1964), who found that in a normal subject continuous intravenous infusion of gastrin at $67.17 \mu \mathrm{g} /$ hour $(\equiv 0.8 \mu \mathrm{g} / \mathrm{kg} / \mathrm{hour})$ produced a near-maximal and at $12.73 \mu \mathrm{g} /$ hour $(\equiv 0.15$ $\mu \mathrm{g} / \mathrm{kg} /$ hour) submaximal acid output.

All the tests were performed on patients fasting overnight. There were two series of observations (Fig. 1a). Series 1 (seven patients) consisted of six consecutive halfhourly observation periods (periods I to VI), which cor- responded to the six periods of the previous pentagastrin study (Misiewicz et al, 1967). After two control periods (periods I and II) devoted to basal measures ments and infusion of dextrose saline, gastrin was infused at the rate of $0.15 \mu \mathrm{g} / \mathrm{kg} / \mathrm{hour}$ for 60 minutes (periodIII and IV), and at the rate of $0.80 \mu \mathrm{g} / \mathrm{kg} / \mathrm{hour}$ for the next 30 minutes (period V). During the last half-hour of the test (period VI) gastric suction was stopped, but measurements of intraluminal pressure were continued and gastrin was administered at the initial rate of $0 \cdot 15$ $\mu \mathrm{g} / \mathrm{kg} /$ hour.

Because the observations carried out in the series 1 tests did not show a clear effect of gastrin on motility, the procedure was modified for the subsequent series 2 tests (five patients). First, pressures in the gastric antrum were measured with a $10 \times 7 \mathrm{~mm}$ air-filled balloon, as well as with an open-ended tip (Fig. 1b); this arrangement was more sensitive to alterations of motility and is further discussed in the technical note below. Secondly, the higher dose of gastrin $(0.80 \mu \mathrm{g} / \mathrm{kg} /$ hour $)$ was employed throughout series 2 in case tachyphylaxis to an initial lower dose prevented the appearance of motility effects. There were again six consecutive observation periods (periods A to F, Fig. 1a), but each period lasted 20 minutes. Basal observations were made during the first hour with dextrose saline infused as a control (periods $A, B$, and C). During the following three periods (D, E, and F), gastrin II was infused at the rate of $0.8 \mu \mathrm{g} / \mathrm{kg} /$ hour, but during the last 20 minutes gastric suction was stopped (period F, Fig. 1a).

COLLECTION AND ANALYSIS OF GASTRIC JUICE Gastric juice was aspirated continuously by a combination of syringe and pump suction through a nasogastric tube positioned under fluoroscopic control. The juice was collected every 10 minutes and the acid measured by titration with $0.1 \mathrm{~N} \mathrm{NaOH}$ to $p \mathrm{H} 7.4$ on an automatic burette (Radiometer, Copenhagen). 

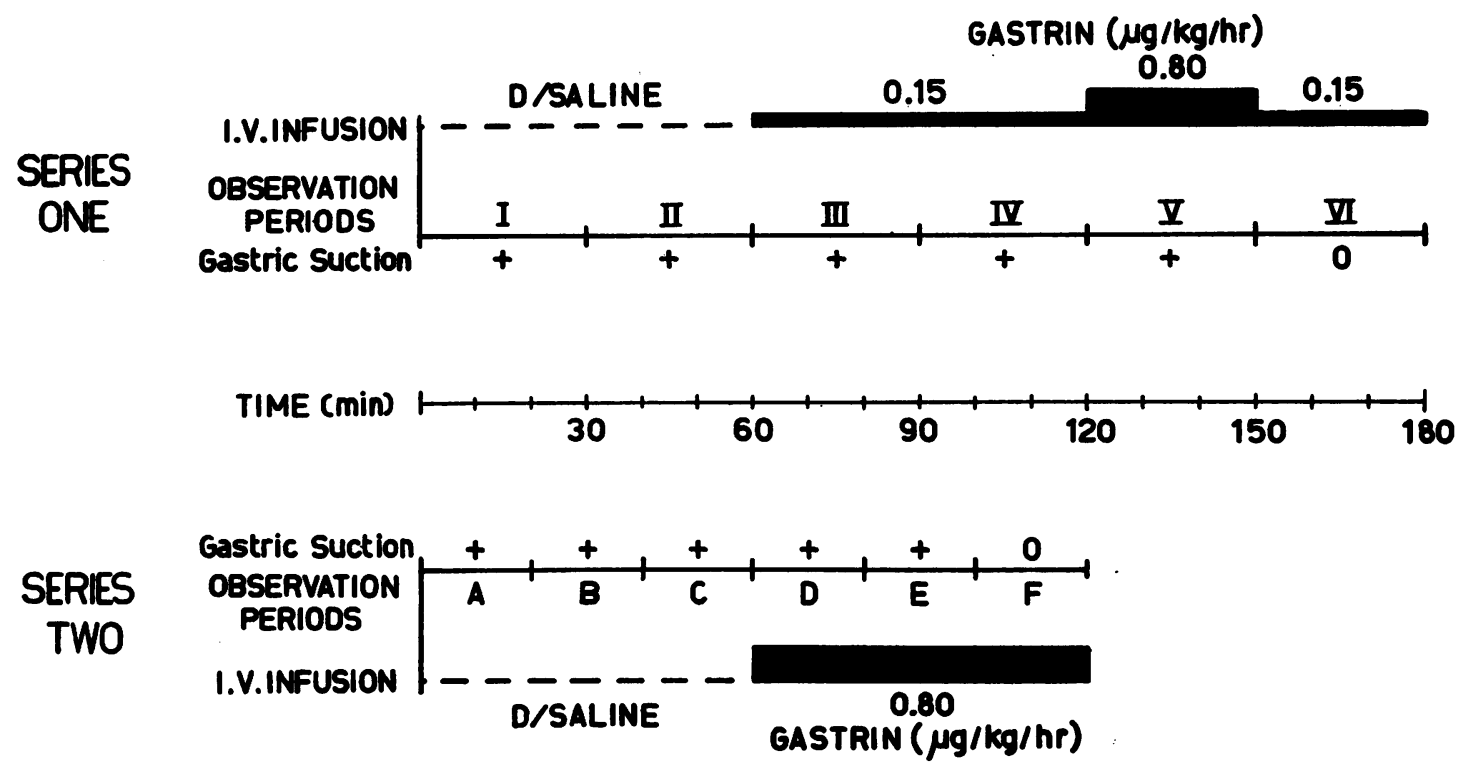

FIG. 1a. Plan of study in series 1 and 2.

MEASUREMENT AND ANALYSIS OF INTRALUMINAL PRESSURES Motor activity in the ascending colon was telemetered with pressure-sensitive radiocapsules (Rowlands and Wolff, 1960), while pressures in the sigmoid and rectum were measured with $10 \times 7 \mathrm{~mm}$ air-filled rubber balloons. Both methods have already been described in detail (Misiewicz et al, 1967).

In series 1 , antral and fundic pressures were measured with fluid-filled, open-ended tubes and recorded continuously on multichannel penwriters (Sanborn and Devices) as described previously (Misiewicz et al, 1967). In series 2, a $10 \times 7 \mathrm{~mm}$ air-filled balloon was included in the gastric tube in addition to the two open-ended tips, and positioned so that the midpoint of the balloon was $1 \mathrm{~cm}$ distal to the antral open-ended tip (Fig. 1b). The location of the gastric suction and pressure tubes and of the radiotelemetering capsule was checked by fluoroscopy before and after each study.

The records of intraluminal pressure were processed in an analogue to digital converter and the digital data analysed by computer, as described by Misiewicz, Waller, Healy, and Piper (1968b). Separate analyses were made of all the records at intervals of $\mathbf{1 0}$ minutes which corresponded to the collections of gastric secretion, but for statistical treatment the results were considered in terms of the observation periods I to VI (series 1) or A to $\mathbf{F}$ (series 2). Variables of motor activity derived from computer analysis included average intensity (motility index), percentage duration of activity, and mean peak height: these terms have been defined already (Misiewicz et al, 1968b).

Some pressure records had to be discarded for tech-

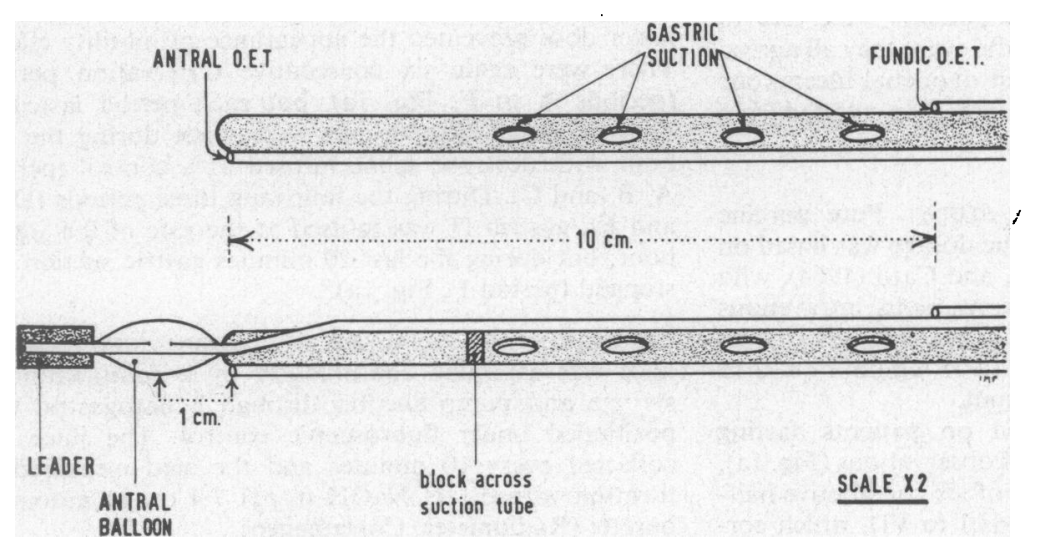

FIG. 1b. Gastric multilumen tubes for series 1 and 2. 
nical reasons, and the number of studies at the various sites available for analysis are shown in Tables I and III. Two-way analysis of variance was used to test for significant differences between levels of motor activity and Student's $\mathbf{t}$ test ior differences between levels of acid output.

TECHNICAL NOTE Open-ended tubes perfused with fluid record true variations of intraluminal pressure about a baseline. However, muscle activity of the gut wall may take place without a recordable rise in intraluminal pressure, for example, when the force of contraction is able to propel the intestinal contents into an adjacent segment without encountering peripheral resistance, or when the contracting segment communicates with a large cavity able to accommodate increments in the volume of its contents, eg, the gastric body.

Small balloons may also record variations of intraluminal pressure in certain circumstances, but when brought in contact with the mucosa (eg, in the antrum) are likely to be deformed by mechanical action of the gut wall. In these circumstances the rise in pressure within the balloon cannot properly be said to represent variations in intraluminal pressure but rather in muscle activity because it is muscle activity which deforms the balloon. The amplitude of pressure waves recorded with a small balloon thus tends to be higher than that recorded with an open-ended tube. For example, the average antral peak height in series 2 during periods $A, B$, and $\mathrm{C}$ was $19.73 \mathrm{~cm} \mathrm{H}_{2} \mathrm{O}$ as recorded by balloon, and $9 \cdot 10$ $\mathrm{cm} \mathrm{H}_{2} \mathrm{O}$ as recorded by open-ended tube. These characteristics of small balloons need not invalidate experimental observations made with them, provided that like data are compared with like, and that the type of information obtained is borne in mind when the results are interpreted. On the contrary, because balloons are more sensitive to variations in muscle activity than open-ended tubes, this property of the recording system can be turned to advantage in the measurement of variations in muscle activity in situations when the latter do not necessarily produce variations in intraluminal pressure. Radiotelemetering capsules can also be used to measure variations of muscular activity in the stomach (for further discussion see Misiewicz, Waller, Fox, Goldsmith, and Hunt, 1968a; Misiewicz, 1968c).

\section{RESULTS}

EFFECTS OF GASTRIN II INFUSION ON ACID SECRETION The gastric secretory responses in series 1 and 2 are shown in Figures $2 a$ and $b$. Intravenous infusion of gastrin II produced a prompt increase in acid output in all the subjects. In series I, a peak in acid output occurred in response to the lower dose of gastrin at about $\mathbf{5 0}$ minutes after the start of gastrin infusion. Before a plateau of secretion could be established, however, the higher dose of gastrin infused during period $V$ resulted in a further increase in gastric secretion (Fig. 2a), which was significantly higher than the level attained in period IV $(P<0.01)$. In patients in series 2 , the data suggest

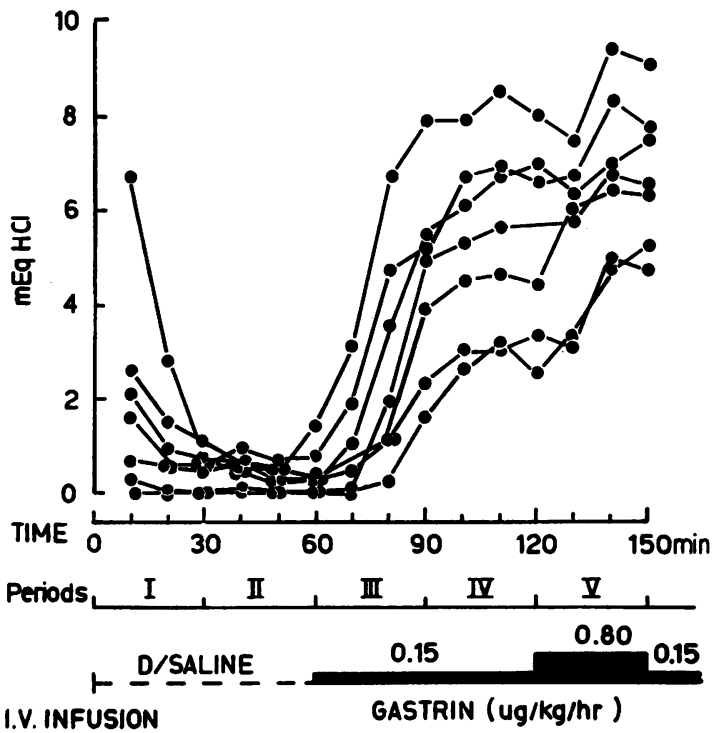

FIG. 2a. Acid output of individual patients in series 1 .

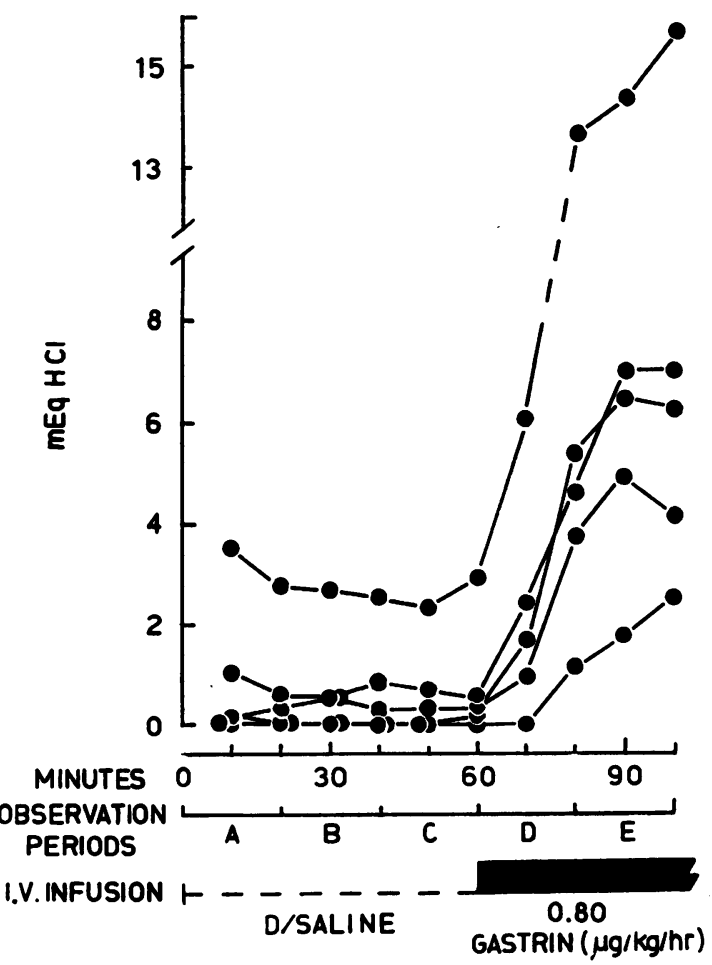

FIG. 2b. Acid output of individual patients in series 2. 
that the peak in output of acid was reached at 30 to 40 minutes after the start of gastrin infusion, ie, somewhat earlier than in the series 1 tests.

EFFECTS OF GASTRIN INFUSION ON MOTOR ACTIVITY The relevant data are shown in Tables I to IV.

Fundus There were no significant changes in any variable of motor activity in either series 1 or 2 during the respective basal periods indicating that the observations were adequately controlled. Gastrin did not affect the motor activity of the fundus in series 1 or 2 at any dose level. (The difference in percentage duration of activity between periods III and IV (Table II), although significant at the 0.05 level, was considered to be due to spontaneous variations in fundic activity, rather than to a specific effect of gastrin, because neither period III nor period IV differed from the basal levels.) When gastric suction was stopped in the presence of continued infusion of gastrin, the percentage duration of fundic activity fell (period VI, series $1, P<0.05$ ), although mean peak height and average intensity remained unchanged (Tables II and IV).

Antrum Observations relating to average intensity and percentage duration of activity were vitiated in the series 1 studies (Table II), because the two basal periods (I and II) differed with regard to these variables $(\mathrm{P}<0.05)$. On the other hand, although data on mean peak height were adequately controlled, there was no significant change in this variable of antral activity at either level of gastrin dosage (periods III, IV, and V). When gastric suction was stopped while gastrin was infused at the lower dose (period VI), antral mean peak height was reduced $(P<0.01)$. It is also worth noting that both average intensity and percentage of activity were

TABLE I

MEAN VALUES \pm SE OF THE MEAN IN INDIVIDUAL OBSERVATION PERIODS IN SERIES 1

\begin{tabular}{|c|c|c|c|c|c|c|c|c|c|}
\hline \multirow{2}{*}{$\begin{array}{l}\text { Site and } \\
\text { (Sensor) }\end{array}$} & \multirow[t]{2}{*}{ Variable of Motility } & \multirow[t]{2}{*}{ No. of Studies } & \multicolumn{6}{|c|}{ Observation Periods (Mean Values) } & \multirow[b]{2}{*}{$S E$} \\
\hline & & & $I$ & $\boldsymbol{I I}$ & $I I I$ & $I V$ & $\boldsymbol{V}$ & $V I$ & \\
\hline $\begin{array}{l}\text { Fundus } \\
\text { (open-ended } \\
\text { tube) }\end{array}$ & $\begin{array}{l}\text { Average intensity (logs) } \\
\text { Duration of activity (\%) } \\
\text { Mean peak height }\end{array}$ & $\begin{array}{l}3 \\
3 \\
3\end{array}$ & $\begin{array}{c}0 \cdot 50 \\
53 \cdot 8 \\
6 \cdot 8\end{array}$ & $\begin{array}{c}0 \cdot 16 \\
42 \cdot 0 \\
5 \cdot 1\end{array}$ & $\begin{array}{c}0.45 \\
55 \cdot 4 \\
5 \cdot 5\end{array}$ & $\begin{array}{c}0 \cdot 20 \\
32 \cdot 6 \\
4 \cdot 2\end{array}$ & $\begin{array}{c}0 \cdot 24 \\
38 \cdot 0 \\
4 \cdot 3\end{array}$ & $\begin{array}{c}-0 \cdot 13 \\
22 \cdot 5 \\
3 \cdot 5\end{array}$ & $\begin{array}{l} \pm 0.20 \\
\pm 6.6 \\
\pm 1 \cdot 6\end{array}$ \\
\hline $\begin{array}{l}\text { Antrum } \\
\text { (open-ended } \\
\text { tube) }\end{array}$ & $\begin{array}{l}\text { Average intensity (logs) } \\
\text { Duration of activity (\%) } \\
\text { Mean peak height }\end{array}$ & $\begin{array}{l}7 \\
7 \\
7\end{array}$ & $\begin{array}{c}0.43 \\
47 \cdot 7 \\
5 \cdot 7\end{array}$ & $\begin{array}{c}0 \cdot 12 \\
39 \cdot 2 \\
4 \cdot 8\end{array}$ & $\begin{array}{c}0 \cdot 27 \\
44 \cdot 5 \\
4 \cdot 5\end{array}$ & $\begin{array}{c}0 \cdot 32 \\
46 \cdot 1 \\
4 \cdot 9\end{array}$ & $\begin{array}{c}0 \cdot 37 \\
46 \cdot 8 \\
5 \cdot 2\end{array}$ & $\begin{array}{c}-0 \cdot 14 \\
28 \cdot 7 \\
2 \cdot 7\end{array}$ & $\begin{array}{l} \pm 0.08 \\
\pm 2.8 \\
\pm 0.2\end{array}$ \\
\hline
\end{tabular}

TABLE II

DIFFERENCES BETWEEN MEANS OF OBSERVATION PERIODS \pm STANDARD ERRORS IN SERIES 1

Site $\quad$ Variable of Motility Periods Compared

\begin{tabular}{lllllll}
\hline$I$ vs II & $I I I$ vs IV & $I, I I v s$ & $I, I I$ vs $V$ & $I, I I$ vs VI & $V$ vs VI & $I I I, I V$ is $V I$
\end{tabular}

\begin{tabular}{|c|c|c|c|c|c|c|c|c|c|c|c|}
\hline undus & $\begin{array}{l}\text { Average intensity (logs) } \\
\text { Duration of activity (\%) } \\
\text { Mean peak height }\end{array}$ & $\begin{array}{c}0 \cdot 34 \\
11 \cdot 8 \\
1 \cdot 7\end{array}$ & $\begin{array}{l} \pm 0 \cdot 29 \\
\pm 9 \cdot 3 \\
\pm 2 \cdot 25\end{array}$ & $\begin{array}{c}0 \cdot 25 \\
22 \cdot 8^{2} \\
1 \cdot 3\end{array}$ & $\begin{array}{l} \pm 0.29 \\
\pm 9 \cdot 3 \\
\pm 2 \cdot 25\end{array}$ & $\begin{array}{l}0.01 \pm 0 \cdot 21 \\
3 \cdot 9 \pm 6 \cdot 6 \\
1 \cdot 1 \pm 1 \cdot 1\end{array}$ & $\begin{array}{l}0 \cdot 10 \pm 0 \cdot 25 \\
9 \cdot 90 \pm 8 \cdot 0 \\
1 \cdot 85 \pm 1 \cdot 9\end{array}$ & $\begin{array}{l}0.47 \pm 0.25 \\
25 \cdot 4^{2} \pm 8 \cdot 0 \\
2.45 \pm 1.9\end{array}$ & $\begin{array}{c}0 \cdot 37 \\
15 \cdot 4 \\
0 \cdot 8\end{array}$ & $\begin{array}{l} \pm 0 \cdot 29 \\
\pm 9 \cdot 3 \\
\pm 2 \cdot 25\end{array}$ & $\begin{aligned} 0.46 & \pm 0.25 \\
21.4^{2} & \pm 8.0 \\
1.4 & \pm 1.9\end{aligned}$ \\
\hline 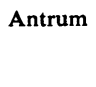 & $\begin{array}{l}\text { Average intensity (logs) } \\
\text { Duration of activity (\%) } \\
\text { Mean peak height }\end{array}$ & $\begin{array}{l}0.31^{2} \\
8 \cdot 5^{2} \\
0 \cdot 9\end{array}$ & $\begin{array}{l} \pm 0 \cdot 12 \\
\pm 4 \cdot 0 \\
\pm 0.9\end{array}$ & $\begin{array}{r}-0.02 \\
-\quad 1.5 \\
0.5\end{array}$ & $\begin{array}{l} \pm 0 \cdot 12 \\
\pm 4 \cdot 0 \\
\pm 0.9\end{array}$ & $\begin{array}{l}-0.01 \pm 0.08 \\
-0.9 \pm 2.7 \\
0.5 \pm 0.6\end{array}$ & $\begin{array}{l}-0.05 \pm 0 \cdot 10 \\
-3.4 \pm 3.4 \\
0.1 \pm 0.8\end{array}$ & $\begin{array}{c}0 \cdot 20^{2} \pm 0 \cdot 10 \\
14 \cdot 8^{2} \pm 3 \cdot 4 \\
2 \cdot 6^{2} \pm 0 \cdot 8\end{array}$ & $\begin{array}{c}0 \cdot 25^{2} \\
18 \cdot 1^{2} \\
2 \cdot 2^{3}\end{array}$ & $\begin{array}{l} \pm 0.12 \\
\pm 4 \cdot 0 \\
\pm 0.9\end{array}$ & $\begin{array}{c}0 \cdot 22^{2} \pm 0 \cdot 10 \\
16 \cdot 6^{1} \pm 3 \cdot 4 \\
2 \cdot 0^{3} \pm 0 \cdot 8\end{array}$ \\
\hline
\end{tabular}

${ }^{1}$ Results and calculations for the colon have been omitted for the sake of brevity but can be obtained on application to J.J.M. or S.L.W. ${ }^{2} \mathrm{P}<0.05$. ${ }^{3} \mathbf{P}<0.01$.

TABLE III

MEAN VALUES \pm SE OF THE MEAN IN INDIVIDUAL OBSERVATION PERIODS IN SERIES 2

\begin{tabular}{|c|c|c|c|c|c|c|c|c|c|}
\hline \multirow{2}{*}{$\begin{array}{l}\text { Site and } \\
\text { (Sensor) }\end{array}$} & \multirow[t]{2}{*}{ Variable of Motility } & \multirow[t]{2}{*}{ No. of Studies } & \multicolumn{6}{|c|}{ Observation Periods (Mean Values) } & \multirow[b]{2}{*}{$S E$} \\
\hline & & & $A$ & $\boldsymbol{B}$ & $C$ & $D$ & $\boldsymbol{E}$ & $\boldsymbol{F}$ & \\
\hline $\begin{array}{l}\text { Fundus } \\
\text { (open-ended } \\
\text { tube) }\end{array}$ & $\begin{array}{l}\text { Average intensity (logs) } \\
\text { Duration of activity (\%) } \\
\text { Mean peak height }\end{array}$ & $\begin{array}{l}4 \\
4 \\
4\end{array}$ & $\begin{array}{c}0 \cdot 24 \\
54 \\
3 \cdot 3\end{array}$ & $\begin{array}{l}0 \cdot 27 \\
57 \\
3 \cdot 2\end{array}$ & $\begin{array}{l}0.08 \\
45 \\
2 \cdot 7\end{array}$ & $\begin{array}{l}0 \cdot 15 \\
47 \\
3 \cdot 2\end{array}$ & $\begin{array}{l}0 \cdot 14 \\
49 \\
3 \cdot 0\end{array}$ & $\begin{array}{l}-0 \cdot 10 \\
36 \\
2 \cdot 5\end{array}$ & $\begin{array}{l} \pm 0.102 \\
\pm 5.4 \\
\pm 0.05\end{array}$ \\
\hline $\begin{array}{l}\text { Antrum } \\
\text { (open-ended } \\
\text { tube) }\end{array}$ & $\begin{array}{l}\text { Average intensity (logs) } \\
\text { Duration of activity (\%) } \\
\text { Mean peak height }\end{array}$ & $\begin{array}{l}5 \\
5 \\
5\end{array}$ & $\begin{array}{c}0 \cdot 20 \\
53 \\
8 \cdot 16\end{array}$ & $\begin{array}{c}0 \cdot 22 \\
44 \\
8 \cdot 64\end{array}$ & $\begin{array}{l}0 \cdot 24 \\
43 \\
10 \cdot 52\end{array}$ & $\begin{array}{c}0 \cdot 22 \\
45 \\
8 \cdot 98\end{array}$ & $\begin{array}{l}0 \cdot 24 \\
50 \\
8 \cdot 20\end{array}$ & $\begin{array}{c}0.08 \\
38 \\
7 \cdot 54\end{array}$ & $\begin{array}{l} \pm 0.096 \\
\pm 3.7 \\
\pm 1.85\end{array}$ \\
\hline $\begin{array}{l}\text { Antrum } \\
\text { (balloon) }\end{array}$ & $\begin{array}{l}\text { Average intensity (logs) } \\
\text { Duration of activity (\%) } \\
\text { Mean peak height }\end{array}$ & $\begin{array}{l}5 \\
5 \\
5\end{array}$ & $\begin{array}{l}0 \cdot 51 \\
44 \\
19 \cdot 10\end{array}$ & $\begin{array}{l}0.25 \\
31 \\
18.84\end{array}$ & $\begin{array}{l}0 \cdot 31 \\
36 \\
21 \cdot 24\end{array}$ & $\begin{array}{l}0 \cdot 55 \\
49 \\
16 \cdot 72\end{array}$ & $\begin{array}{l}0.44 \\
50 \\
13.38\end{array}$ & $\begin{array}{l}0.17 \\
29 \\
13.64\end{array}$ & $\begin{array}{l} \pm 0.134 \\
\pm 7 \cdot 2 \\
\pm 5 \cdot 3\end{array}$ \\
\hline
\end{tabular}


TABLE IV

DIFFERENCES BETWEEN MEANS OF OBSERVATION PERIODS \pm STANDARD ERRORS IN SERIES 2

\begin{tabular}{|c|c|c|c|c|}
\hline \multirow{2}{*}{$\begin{array}{l}\text { Site }{ }^{1} \text { and } \\
\text { (Sensor) }\end{array}$} & \multirow[t]{2}{*}{ Variable of Motility } & \multicolumn{3}{|c|}{ Periods Compared } \\
\hline & & $\begin{array}{l}A, B \\
D, E\end{array}$ & vs & $D, E v s F$ \\
\hline \multirow{2}{*}{$\begin{array}{l}\text { Fundus } \\
\text { (open-ended } \\
\text { tube) }\end{array}$} & A verage intensity & 0.05 & \pm 0.094 & $0.25 \pm 0.126$ \\
\hline & $\begin{array}{l}\text { Duration of activity } \\
(\%) \\
\text { Mean peak height }\end{array}$ & $\begin{array}{l}5 \\
0\end{array}$ & \pm 5.0 & $\begin{array}{c}12 \pm 6 \cdot 6 \\
0.60 \pm 0 \cdot 57\end{array}$ \\
\hline \multirow{3}{*}{$\begin{array}{l}\text { Antrum } \\
\text { (open-ended } \\
\text { tube) }\end{array}$} & Average intensity & 0.02 & \pm 0.088 & $0 \cdot 15 \pm 0 \cdot 118$ \\
\hline & Duration of activity & -1 & $\pm 3 \cdot 4$ & $9^{2} \quad \pm 4 \cdot 5$ \\
\hline & Mean peak height & $-2 \cdot 59$ & $\pm 1 \cdot 7$ & $5 \cdot 25^{2} \pm 2 \cdot 27$ \\
\hline \multirow{2}{*}{$\begin{array}{l}\text { Antrum } \\
\text { (balloon) }\end{array}$} & Average intensity & -0.13 & $\pm 0 \cdot 122$ & $0.33^{2} \pm 0.164$ \\
\hline & $\begin{array}{l}\text { (logs) } \\
\text { Duration of activity } \\
(\%) \\
\text { Mean peak height }\end{array}$ & $\begin{array}{r}-12^{3} \\
4 \cdot 67\end{array}$ & $\begin{array}{l} \pm 3 \cdot 3 \\
+4 \cdot 85\end{array}$ & $\begin{array}{l}21^{3} \pm 4.4 \\
1.41+6.50\end{array}$ \\
\hline
\end{tabular}

${ }^{1}$ Results for the colon as for Table II.

${ }^{2} P<0.05$.

${ }^{3} \mathbf{p}<0.01$.

lower in period VI than in any other single observation period of the series 1 tests $(P<0.05)$.

In series 2 (Tables III and IV), data recorded both by the antral balloon and the open-ended tip were adequately controlled with regard to all the three variables of motor activity (periods $\mathrm{A}, \mathrm{B}$, and $\mathrm{C}$ ). Observations made with the open-ended tip showed no significant change in any variable of activity during infusion of gastrin (periods $D$ and $E$ ), but when gastric suction was stopped in period $F$, percentage duration of activity and mean peak height of antral motility were diminished, despite continuing administration of gastrin at the higher dose (percentage duration of activity, $P<0.05$; mean peak height, $P<0.05$ ).

By contrast, analysis of records made with the antral balloon revealed an increase in percentage duration of activity during the infusion of gastrin (periods $D$ and E, $P<0.01$ ), but average intensity and mean peak height remained unchanged $(P>0.30$ and $>0.40$, respectively). On the other hand, diminution of antral motility in period $F$ (no gastric suction) was apparent on analysis of both average intensity $(P<0.05)$ and percentage duration of activity $(\mathrm{P}<0.01$, Table IV).

Colon There were no significant differences with respect to any variable of colonic motor activity during the basal periods in either series of observations (periods I and II, series 1 and A, B, and C, series 2). Analysis of the data did not show any significant change in the level of any variable of motor activity in any part of the colon that was studied, regardless of the dose of gastrin, or of the presence or absence of gastric suction (periods III, IV, V, ard VI, series 1; and D, E, and F, series 2).

\section{DISCUSSION}

The pattern of gastric acid output stimulated by continuous infusion of gastrin in this study resembles that previously described by Makhlouf et al (1964), although the achievement of a plateau response following the peak secretion was prevented by the experimental design.

Analysis of the pressure records indicates that gastrin stimulated the motor activity of the antrum. On the other hand no change was detected in the gastric fundus, and motility of the right colon, sigmoid, and rectum remained unaffected. These conclusions agree with previous studies using pentagastrin (Misiewicz et al, 1967), and are further supported by observations on isolated strips of human alimentary muscle studied with gastrin or its synthetic analogue (Bennett, Misiewicz, and Waller, 1967). It is therefore likely that motor effects of gastrin in man are limited to the stomach. There is no evidence from these studies that gastrin plays a major role in the mediation of the gastro-colic reflex, and this view is strengthened by the observation of Holdstock and Misiewicz (in press), that the greatest motor response to food occurred in the sigmoid colon of patients with total gastrectomy, $i e$, in the absence of the main gastrin-secreting area. The present authors agree with Grossman (1968) that studies of intestinal responses to gastrin (Smith and Hogg, 1966) or pentagastrin (Logan and Connell, 1966) given by rapid intravenous injection are difficult to interpret, partly because endogenous gastrin is unlikely to be released in this manner, but also because these workers did not exclude the consequence of acid entering the intestine, which in turn may provoke alterations in motility by mechanical distension or by the release of other polypeptide hormones: the prolonged stimulation of acid output after single intravenous injections of gastrin is well known (Makhlouf et al, 1964).

Neither gastrin (present results) nor pentagastrin (previous study) appeared to stimulate the motor activity of the fundus, but such an effect cannot be conclusively ruled out by the techniques employed to measure intraluminal pressure, since activity of the fundic wall may take place without detectable changes in this variable of motility (Misiewicz, 1968c). Further tests with devices sensitive to alterations of muscle activity, such as radiotelemetering capsules or large balloons in contact with the fundic mucosa, would help to settle this point.

Although stimulation of antral motor activity by gastrin has bəen shown here by statistical analysis of 
the results, the effect was not marked and was demonstrable with regard to one variable of motility only by the more sensitive of the two pressure-measuring devices placed in the gastric antrum. On the basis of present results alone it is therefore difficult to decide whether the observed effects are of physiological significance. Gastric motility increases after meals, and although the release of endogenous gastrin may be partly responsible, numerous other factors, such as vagal activity or mechanical distension, must be taken into account. On the other hand the experiments of Hunt and Ramsbottom (1967) agree with the present observations. They recorded a delay in the gastric emptying time of a buffered liquid meal in response to infusions of gastrin at dose levels similar to those used in the present study. The delay may have been due to increased muscle tone, which is supported to some extent by the present finding of increased percentage duration of antral activity caused by gastrin. As gastric emptying in patients with gastric ulcer is slower than in normal persons or in patients with duodenal ulcer (Griffith, Owen, Campbell, and Shields, 1968; George, 1968), measurements of circulating gastrin in these conditions by immunoassay are eagerly awaited.

Stimulation of antral motility by gastrin was much less striking than that previously observed with pentagastrin. Infusions of pentagastrin increased both the antral percentage duration of activity and the mean peak height, with a consequent rise in motility index, as measured by the open-ended tube (Waller, unpublished data). In contrast, no increase in motility in response to gastrin was apparent with the less sensitive method, while measurements with the small balloon showed an increased percentage actıvity but no change in mean peak height. Comparisons between the dosage levels of the two substances are difficult and their effects were studied in different subjects. On the other hand, gastrin and the synthetic analogue were both infused in doses producing near-maximal levels of gastric secretion, and mean acid output in the present series of patients is similar to the output in the group investigated previously with pentagastrin (Misiewicz et al, 1967).

It appears therefore that doses of gastrin and pentagastrin which produce similar levels of acid output have different effects on antral motility, and this difference has been clinically commented on by others (Makhlouf, McManus, and Card, 1966).

The explanation of these differences between the action of gastrin and pentagastrin must remain conjectural, although it is likely that they are a function of differences in the molecular structure of the two compounds. Both appear to contract human gastric muscle cells in vitro by direct action, pre- sumably activating the same receptor sites (Bennett et al, 1967). All the biological activity of the gastrin molecule resides in the C-terminal tetrapeptide sequence (Tracy and Gregory, 1964), while it has been argued that the tridecapeptide residue is concerned with facilitating the transport of the active fragment to the site of acid-secretory action (Morley, 1968). In the cat, the half-life of gastrin extract (or of pentagastrin) in the peripheral circulation is very short, yet stimulation of gastric secretion persists long after the secretagogue has been cleared from the blood (Blair and Wood, 1968), suggesting avid binding by the target organ. It may be that acid-secretory receptors with high affinity for gastrin compete for it with receptors situated on smooth muscle cells. On the other hand, transport of the pentagastrin molecule to the gastric secretory receptors may be less efficient because of the absence of the tridecapeptide moiety, thus leaving more pentagastrin to act on the muscle cells. Moreover, variations in the $\mathrm{N}$-terminal unit joined to the tetrapeptide amide are known to modify physiological properties, other than acid stimulation. For example, the $\mathrm{N}$-terminal unit of cerulein is a hexapeptide. This substance causes powerful contraction of the gall bladder, which is relatively insensitive to gastrin or its analogue (Bertaccini, De Caro, Endean, Erspamer, and Impiccciatore, 1967; Mack and Todd, 1968). Indeed in the dog the relative cholecystokinetic potency of various peptides with the same C-terminal sequence seems to depend on the N-terminal group (Vagne and Grossman, 1968).

We are grateful to Dr F. Avery Jones and Dr T. D. Kellock for allowing us to study their patients. We thank Professor R. A. Gregory and Dr D. J. Fitzgerald, ICI, for the generous gift of pure porcine gastrin II, and $\mathbf{M r}$ M. J. R. Healy, Medical Research Council Clinical Research Centre, Statistical Division, for advice on statistical methods. We are indebted to Mrs Vivien Binks for expert technical help, to Miss Nancy Kiley, Mrs I. Prentice, and Mr A. G. Booker, FPS, for the illustrations, and to Mrs P. A. Stuart for secretarial assistance.

\section{REFERENCES}

Bennett, A., Misiewicz, J. J., and Waller, S. L. (1967). Analysis of the motor effects of gastrin and pentagastrin on the human alimentary tract in vitro. Gut, 8, 470-474.

Bertaccini, G., De Caro, G., Endean, R., Erspamer, V., and Impicciatore, M. (1967). The actions of caerulein on the smooth muscle of the gastrointestinal tract and the gall bladder. Brit. J. Pharmacol., 34, 291-310.

Blair, E. L., and Wood, D. D. (1968). The estimation of gastrin activity in blood. J. Physiol. (Lond), 194, 44-45 P.

George, J. D. (1968). New clinical method for measuring the rate of gastric emptying: the double sampling test meal. Gut, 9, 237242.

Griffith, G. H., Owen, G. M., Campbell, H., and Shields, R. (1968). Gastric emptying in health and in gastroduodenal disease. Gastroenterology, 54, 1-7. 
Grossman, M. I. (1968). Physiological role of gastrin. Fed. Proc., 27, 1312-1313.

Hunt, J. N., and Ramsbottom, N. (1967). Effect of gastrin II on gastric emptying and secretion during a test meal. Brit. med. J., 4, 386-387.

Logan, C. J. H., and Connell, A. M. (1966). The effect of a synthetic gastrin-like pentapeptide (ICI 50,123) on intestinal motility in man. Lancet, 1, 996-999.

Mack, A. J., and Todd, J. K. (1968). A study of human gall bladder muscle in vitro. Gut, 9, 546-549.

Makhlouf, G. M., McManus, J. P. A., and Card, W. I. (1964). Doseresponse curves for the effect of gastrin II on acid gastric secretion in man. Ibid., 5, 379-384.

,,--- (1966). Action of the pentapeptide (ICI 50,123) on gastric secretion in man. Gastroenterology, 51, 455-465.

Misiewicz, J. J., Holdstock, D. J., and Waller, S. L. (1967). Motor responses of the human alimentary tract to near-maximal infusions of pentagastrin. Gut, 8, 463-469.

—, Waller, S. L., Fox, R. H., Goldsmith, R., and Hunt, T. J. (1968a). The effect of elevated body temperature and of stress on the motility of stomach and colon in man. Clin. Sci., 34, 149-159. -, Healy, M. J. R., and Piper, E. A. (1968b). Computer analysis of intraluminal pressure records. Gut, 9, 232-236.

- (1968c). Measurement of intraluminal pressures. Amer. J. dig. Dis., 13, 389-396.

Morley, J. S. (1968). Structure-function relationships in gastrin-like peptides, Proc. roy. Soc. B., 170 97-111.

Rowlands, E. N., and Wolff, H. S. (1960). Telemetering from the digestive tract. Brit. Comm. Electron., 7, 598-601.

Rune, S. J. (1966). Comparison of the rates of gastric acid secretion in man after ingestion of food and after maximal stimulation with histamine. Gut, 7, 344-350.

Smith, A. N., and Hogg, D. (1966). Effect of gastrin II on the motility of the gastrointestinal tract. Lancet, 1, 403-404.

Tracy, H. J., and Gregory, R. A. (1964). Physiological properties of a series of synthetic peptides structurally related to gastrin $I$. Nature (Lond.), 204, 935-938.

Vagne, M., and Grossman, M. I. (1968). Cholecystokinetic potency of gastrointestinal hormones and related peptides. Amer. J. Physiol., 215, 881-884. 